\title{
The Australian housing supply myth
}

\author{
Cameron K. Murray*
}

February 14, 2020

\begin{abstract}
Australia's expensive housing market is claimed to be primarily the result of a shortage of supply due to town planning constraints, leading to political pressure on councils and state governments to remove planning regulations, regardless of their planning merit. We argue that this supply story is a myth and provide evidence against three key elements of the myth. First, there has been a surplus of dwellings constructed compared to population demand, rather than a shortage. Second, planning approvals typically far exceed dwelling construction, implying that more approvals or changes to planning controls on the density and location of development cannot accelerate the rate of new housing supply. Third, large increases in the rate of housing supply would have small price effects relative to other factors, like interest rates, and come with the opportunity cost of forgone alternative economic activities. Indeed, if the story were true, then property developers would be foolishly lobbying for policy changes that reduce the price of their product and the value of the balance sheets, which mostly comprise undeveloped land.
\end{abstract}

Keywords: Housing supply, Home prices, Planning, Housing policy.

\section{Introduction}

In many capital cities in Australia there is a housing affordability crisis which needs to be addressed through increasing housing supply, planning reform and stamp duty taxation reform. Falling house prices are not correcting the pent-up demand and years of lack of supply. (UDIA, 2019)

Economists and policymakers in Australia have argued that too few new homes are being built because of restrictive town planning regulations, leading to lower housing supply and higher home prices (Kendall \& Tulip, 2018; Daley et al. , 2019; Productivity Commission, 2017; UDIA, 2019). This has become the "official story" of many state and federal agencies regarding the primary cause of rising home prices in Australia (Department of the Senate, 2008; COAG, 2012; NHSC, 2013). Indeed, this supply shortage story has also come to dominate discussions about home price growth in the United Kingdom and the United States. ${ }^{1}$

Yet over the past decade, Australia has experienced record new housing construction. The rapid pace of housing construction is thought to be one of the underlying causes of the emerging

\footnotetext{
*Henry Halloran Trust, The University of Sydney, Camperdown NSW 2006. Email: c.murray@sydney.edu.au

${ }^{1}$ Yglesias (2012) and Glaeser \& Gyourko (2018) have been particularly influential at popularising this view in the United States, while in the United Kingdom many think-tanks and government agencies continue to argue this position, such as DCLG (2017), Philp (2017), and Wilson \& Barton (2018), amongst many more summarised in Mulheirn's (2019) critique of the supply story.
} 
construction quality crisis in new apartment towers (Loseby, 2019). ${ }^{2}$ Is it possible that Australian cities have built record numbers of new dwellings, triggering a construction quality crisis, while at the same time planning regulations have been a handbrake on new housing supply, forcing up prices?

We answer here in the negative and claim that the story of planning regulations constraining the rate of housing supply and causing higher prices is a myth. We provide three main pieces of evidence against three key components of the housing supply myth. First, we look at the number of dwellings constructed to show that there has been a sustained increase in dwellings per person since the 1990s, and since 2008, far more than forecast requirements, indicating, if anything, an over-supply of new housing. Second, we debunk the connection between planning and supply by showing that there is no mechanism which forces more new housing on to the market just because the planning system has created a different set of development options for landowners. Planning approvals have routinely exceeded dwelling construction, and developers regularly reduce the rate at which they supply housing even when they hold surplus planning approvals. We explain how relaxing planning controls may also back-fire by providing incentives for landowners to slow down housing development. Third, we debunk the part of the story that claims that supply has a substantial price effect by showing that prices are not particularly sensitive to the rate of new housing supply. Under plausible scenarios of increased construction rates for a ten year period, the effect on prices would be in the $2.4-14.4 \%$ range, depending on assumptions.

We also offer a warning; that the apartment construction quality crisis may contribute to reducing the rate of supply in the coming years, further fuelling the supply-side myth and bringing about political pressure on planners and councils to abandon planning controls, especially those that constrain density in any way. This will happen because new housing supply only occurs in response to demand-new housing is a build-to-order production system, just like most large capital products (like ships, trains, aircraft, and more). If buyer preferences shift away from new housing towards existing housing, because of construction quality risk, then for a given level of demand, fewer buyers will purchase new homes, decreasing the rate of supply.

Other factors may contribute to shifting buyer demand profile towards existing housing. Australian banks have responded to the Royal Commission into Misconduct in the Banking, Superannuation and Financial Services Industry (the "Royal Commission") by more appropriately priced the risk of investor lending compared to owner-occupied lending. The interest rate gap between mortgage types has grown from $0.25 \%$ points to $0.58 \%$ points since 2016 (RBA, 2019). Since owner-occupiers are less likely to buy new and off-the-plan apartments compared to existing homes, this shifts the buyer towards existing housing (CoreLogic, 2016). Another factor is the reduction in foreign purchases of Australian housing, which were 10-15\% of new home sales in 2012-15 but only 5\% of existing home sales (Kearns, 2017). Foreign investment in real estate has collapsed since 2014-15, down 73\%, reducing demand for new and off-the-plan apartments (FIRB, 2018).

\footnotetext{
${ }^{2}$ The crisis had been many years in the making. In 2014, the 21-storey Lacrosse apartment tower in Melbourne's Docklands district suffered a major fire due to numerous design defects, including the use of flammable aluminium composite cladding (Hanmer, 2019). Audits of the use of flammable cladding in New South Wales and Victoria have found that hundreds of buildings have potentially non-compliant flammable cladding (Victorian Cladding Taskforce, 2019). High profile cases of poor construction quality at Opal Tower and Mascot Towers in Sydney have resulted in buildings remaining unoccupied indefinitely (Casben, 2019). A review of 212 residential building defect reports found that " $85 \%$ of all the buildings had at least one defect across multiple locations", with 14 line-item defects found per building on average (Johnston \& Reid, 2019, p.21). Most Australian States have set up inquiry processes to examine the extent of the building quality crisis (ACT Legislative Assembly, 2018; NSW Parliament, 2019).
} 
The combined demand-side effect of these events - the construction quality crises, the relative mortgage interest rate reduction for owner-occupiers, and the fall in foreign buying - is likely to lead to a lower rate of new supply in the next housing cycle. This will not be due to state and council planning regulations constraining supply, but because the profile of housing demand has shifted towards existing homes.

This type of buyer preference shift happened in 2008-09 during the financial crisis, with the demand for new dwellings falling relative to existing dwellings. Figure 1 shows the number of new dwellings purchased (hence built) as a share of total housing turnover, which saw a fall in 2008-09, and again in 2011-12, with both periods resulting in rising prices and a short-term undersupply of new dwellings compared to population growth. ${ }^{3}$ Just as the reduced supply in these periods was a response to demand shits, so too will the be the next period of lower supply. Nevertheless, it will fuel the supply myth.

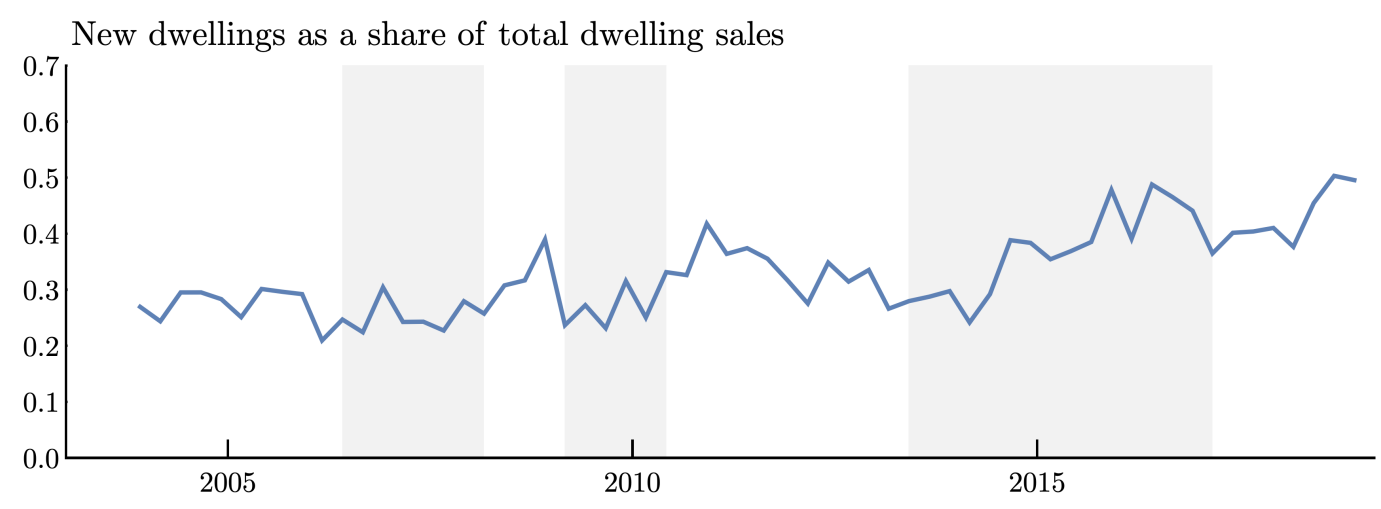

Figure 1: New dwelling sales as a share of total dwelling turnover

The analysis that follows does not imply that planning regulations cannot be improved and simplified. They certainly can. Nor does it make claims about the economic costs and benefits of planning controls on density or location, or the quality of administrative processes in each State's planning system.

\section{The political economy of the supply myth}

The housing supply myth is that overly burdensome planning controls have constrained the rate of housing construction, reducing density, and adding costs to the construction of new dwellings. Supply and demand logic implies that prices are higher than they otherwise would be.

While the supply myth seems intuitively appealing, it is wrong on its substance (as we will later show) and is obvious political rent-seeking. This is plain to see. Assume that the myth is true, then assess the economic consequences for the housing developers who perpetuate the myth to help lobby for more relaxed planning controls. Can it be the case that companies in the business of selling housing are lobbying for a policy that increases competition and reduces the price of their product?

\footnotetext{
${ }^{3}$ The method used to construct this ratio is to divide the change in private housing stock by housing turnover from Table 6 of ABS (2018b). Shaded periods are when smoothed annual price growth exceeded $2 \%$ for at least four consecutive quarters.
} 
The negative economic effect on housing development companies from more competition and lower home prices is amplified by the fact that landbanks dominate their balance sheets. The value of these landbanks would immediately collapse if changing planning controls increased supply from competitors and decreased prices. For example, Stockland holds a $\$ 3.5$ billion residential landbank, and Lendlease holds a $\$ 4$ billion (Stockland, 2019; Lendlease, 2019) landbank. A $20 \%$ decline in home prices would require at least a $\$ 2.4$ billion write-down for just these two developers. ${ }^{4}$ Either property developers are terrible lobbyists run by irresponsible directors who support policies that would wipe billions in shareholder value, or the housing supply myth is a lie. Previous analysis has shown that when publicly listed property developers are required by law not to mislead, such as in their annual reports to investors, they do not claim that the planning system is constraining supply. Instead, they tell investors that they intend to be flexible and slow when supplying housing to maximise profits over time (Murray, 2019).

But the truth does not matter. Cloaked with plausible myths, the economic incentives of vested interests can quickly become entrenched in the policy environment Murray \& Frijters (2017). In 2012 the Australian government set up a supply oversight committee, the National Housing Supply Council (NHSC), to assess the rate of housing supply and make forecasts about future housing needs. This organisation validated the supply myth, and its routine reporting resulted in media coverage favouring developer interests.

To demonstrate how this myth became the "official story" on home prices, the top panel of Figure 4 shows the number of major government reports about housing supply each year (as compiled by Gurran \& Phibbs (2013), with updates from 2012). ${ }^{5}$ The myth was first officially acknowledged in 2003, starting with the Prime Minister's Taskforce, and by 2012 repeated reporting had led to calls to create the NHSC, which itself produced numerous reports repeating the supply myth.

The second panel of Figure 4 shows the Google search trend interest for the terms "housing shortage" and "housing supply" in Australia. Notably, the public interest in housing supply rises during periods of high price growth (shaded areas) and falls away as prices fall. As will be shown later, these high price growth periods do not correspond to low supply. The myth appears to be fuelled by price dynamics, regardless of actual supply conditions.

What makes the housing supply myth so appealing is that it allows governments to shed responsibility for policies that would make housing cheaper. If high prices are due to planning controls, then the solution to them is to change the planning system. Public housing, changing tax incentives, regulation of bank credit, or better rental protections, all no longer make sense as solutions once the problem has been identified as restrictive planning controls.

The myth also helps satisfy a very real political calculus. The $70 \%$ of home-owning households want their $\$ 7$ trillion of housing value to be increased, not eroded. Governments can ensure home prices remain expensive while pretending to care about housing affordability by pushing "placebo policy" focussed on planning controls (McConnell, 2018).

While the economic incentives of home-owners fuel the political popularity of the housing supply myth, the myth's origin stems from the financial motives of housing developers. Housing developers can make windfall gains by buying sites at a price reflecting one type of allowable use, then

\footnotetext{
${ }^{4}$ This is higher than the $20 \%$ home price decline because land makes up $65 \%$ of the home values (Kendall \& Tulip, 2018), amplifying the effect of home price reductions on the land values. A $20 \%$ home price reduction where land makes up $65 \%$ of the price is a $31 \%$ land price reduction. In lower value areas, the amplification effect will be more substantial. Land values in Brisbane are around half dwelling values, meaning a $20 \%$ home price decline would result in a $40 \%$ land value decline.

${ }^{5}$ The shaded areas of the chart show the boom periods when prices increased by more than a $2 \%$ per annum rate for at least four quarters.
} 

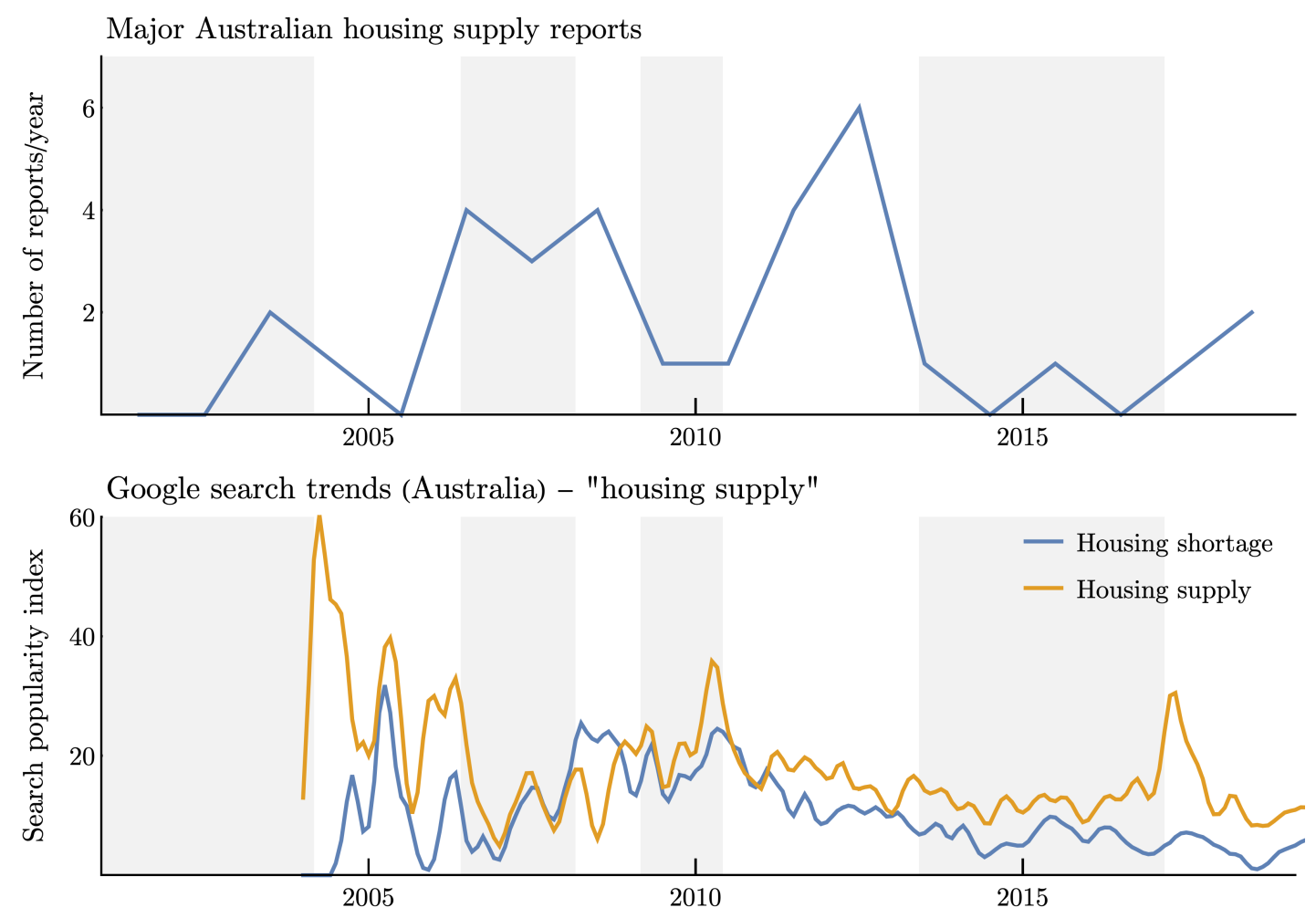

Figure 2: Interest in supply — major report frequency (top), Google search trends (bottom)

lobbying for the right to develop to a higher value use at no extra cost through the planning system. For example, the market value of a site where the allowable highest value use is a townhouse subdivision might be $\$ 3$ million, based on the estimated revenue from development minus construction and development costs. If the planning system then allows a seven-storey apartment building instead, the site might be worth $\$ 10$ million, being the residual of the apartment values minus the construction costs of this more dense development. The $\$ 7$ million difference is a windfall gain transferred from society to the developer through the planning system.

Although the planning system gives away these valuable development rights routinely, they come with no obligation to build the promised dwellings promptly. Landowners who gain generous planning decision can walk away with the windfall gain by selling the site before constructing any dwellings. This is not the case in the Australian Capital Territory (ACT). There, landowners pay a $75 \%$ tax on the gain from planning changes when they mak an application to use the land for the higher density, higher value, use (Murray \& Frijters, 2017). If this tax was enacted Australia-wide, it would raise $\$ 11$ billion per year. Instead, this gain goes to landowners and developers who are best able to influence the planning system.

\section{Is there really a housing shortage?}

Very few researchers or policymakers have questioned the story that town planning regulations constrain housing supply leading to higher home prices, either in Australia, or globally (Phillips 
\& Joseph, 2017; Mulheirn, 2019). What makes the supply myth questionable from the start is that the rising home price trend from 2012 to 2017 was global, therefore making it unlikely to be the product of local planning regulations that by chance were common in many top-tier cities around the world. In that period, Australian home prices increased by $46 \%$. Sydney and Melbourne experienced $74 \%$ and $50 \%$ price growth, respectively (ABS, 2018b). In the same period, the U.S. 20-city composite index increased 41\%, with cities such as San Fransisco (76\%) and Los Angeles (56\%) showing high price growth and some cities like New York showing unexpectedly low growth of $15 \%$. Even in cities thought to have limited planning controls, like Atlanta, Houston and Dallas, prices increased $48 \%, 40 \%$ and $47 \%$ respectively, and continued rising throughout 2018 and 2019, unlike in major Australian cities (S\&P, 2019). Canadian home prices were up 51\% and U.K. prices up 31\% over this period (ONS, 2019; CREA, 2019). Yet all these countries and cities have different planning regimes, with some known for having few, if any, zoning controls.

This section outlines the evidence against the part of the supply myth that claims that housing supply has not sufficiently responded to population growth, generating a shortage. First, we show that key markets like Sydney would be classified as "lightly regulated" with "responsive supply" according to the permitting intensity metrics preferred by some academic proponents of the myth. Second, we look at the historical patterns of new dwelling supply and population change to show that, if anything, there has been a surplus of new dwellings built in Australia over the past two decades. Third, we compare the observed supply and population change over the past decade to earlier forecasts of housing need, showing that reality far exceeded forecasts in terms of new housing supply relative to population growth.

\subsection{Permitting intensity}

A metric thought to be an indicator of the responsiveness of planning system in allowing more new housing is "permitting intensity", or the number of new dwellings given permits by planning authorities in a year compared to the stock of existing dwellings (Glaeser \& Gyourko, 2018). When analysing U.S. housing markets, the Atlanta, Georgia, urban region has been held up as an area with high permitting intensity, and thus responsive housing supply. The Houston, Texas, urban region is another area known for its responsive housing supply (Saiz, 2010). Yet, as we show in Figure 3, the permitting intensity in Sydney has exceeded that seen in both these cities over the last decade. If these two U.S. cities can be said to have responsive housing supply, unrestricted by planning regulation, then the same must be said about Sydney (ABS, 2016; USCB, 2018a,b; NSW Government, 2018; USCB, 2019a,b). ${ }^{6}$

\subsection{Excess of new dwellings per new person}

Though a popular metric, permitting intensity does not account for population trends. It is therefore insufficient to accurately gauge the adequacy of housing supply, especially when cities are growing rapidly. A better measure is the excess new dwellings constructed compared to what would be required by the additional population if they occupied housing with the same number of people per dwelling as the existing population.

The top panel of Figure 4 shows that by this measure, new housing supply in Australia has exceeded demand in 67 of the past 91 quarters for a cumulative "over-supply" since 1996 of 458,000 dwellings (ABS, 2018b). The effect of this supply rate on the number of dwellings per person is in the bottom panel of Figure 4. Dwellings per 1,000 persons increased $5.6 \%$ in total

\footnotetext{
${ }^{6}$ Sydney data is available in the most recent census year of 2016 .
} 


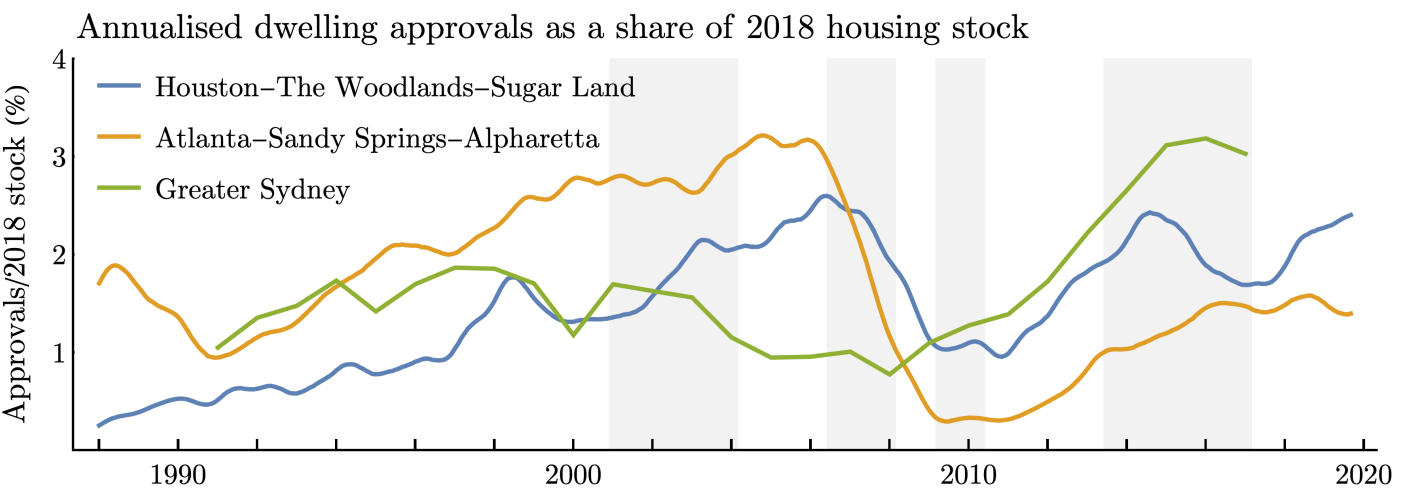

Figure 3: Dwelling approvals as a share of 2018 housing stock (2016 stock for Sydney)

since March 1996 to a record high of 408 (or put another way, 2.45 persons per dwelling, down from 2.59 in 1996). ${ }^{7}$ Despite fewer persons per dwelling, the number of bedrooms in private dwellings has increased from 1.07 per person to 1.23 per person since 2005 (ABS, 2018a).

The $1.5 \%$ decline in private dwellings per person from 2007 to 2014 is likely to have had a price effect, but any effect should have been reversed by the end of 2016 when the relative supply of dwellings regained its previous peak. If supply was a key factor explaining prices, then the rate of supply experienced overall since the late 1990s should have had a negative price effect, as it exceeded population growth. Additionally, it is difficult to see how a planning system that changes slowly can cause the rapid variation observed in excess housing supply. If planning is to be blamed for the periods of under-supply, there is no apparent reason why it should not also be credited for the periods of over-supply.

Another factor to consider is that the above calculations take into account the total population, including people who reside in non-private dwelling accommodation, such as nursing homes, student accommodation, staff housing, and other institutional situations. However, only private dwellings are in the dwelling count. People residing in non-private accommodation do not represent a demand for private dwellings and ideally should be removed from any analysis of supply and demand. Yet this process is not as simple as it appears because of data limitations.

Between 2001 and 2016 the number of people residing in non-private dwellings increased by 220,000 , which is 70,000 more than expected if the number grew at the same rate as the rest of the population (Phillips \& Joseph, 2017). Since that time, the trend is likely to have become more extreme, particularly due to the rapid increase in purpose-built student accommodation (PBSA). Industry research shows that there were 94,000 PBSA beds at the end of 2017, and based on construction commitments at the time, a predicted 120,000 beds by the end of 2019 Knight Frank (2018). In the 2016 census, only 69,000 people lived in student accommodation.

Accounting for the extra 70,000 people in non-private dwellings from 2001 to 2016 (above the amount expected by population growth), plus the additional 40,000 students in PBSA since that

\footnotetext{
${ }^{7}$ This contrasts with OECD data that shows a decline in dwellings per 1000 persons aged over 21 from 411 in 2010 to 401 in 2015, which has been relied upon to claim a shortage of supply is leading to large price effects (Daley et al. , 2019, p.67). ABS data confirms this pattern, with 547 dwellings per 1,000 adults over age 21 in 2001 and 536 in 2015, a 2\% decrease. However, it also shows that in 2018 that this measure was 541 dwellings compared to 539 dwellings in 1996, a slight increase.
} 

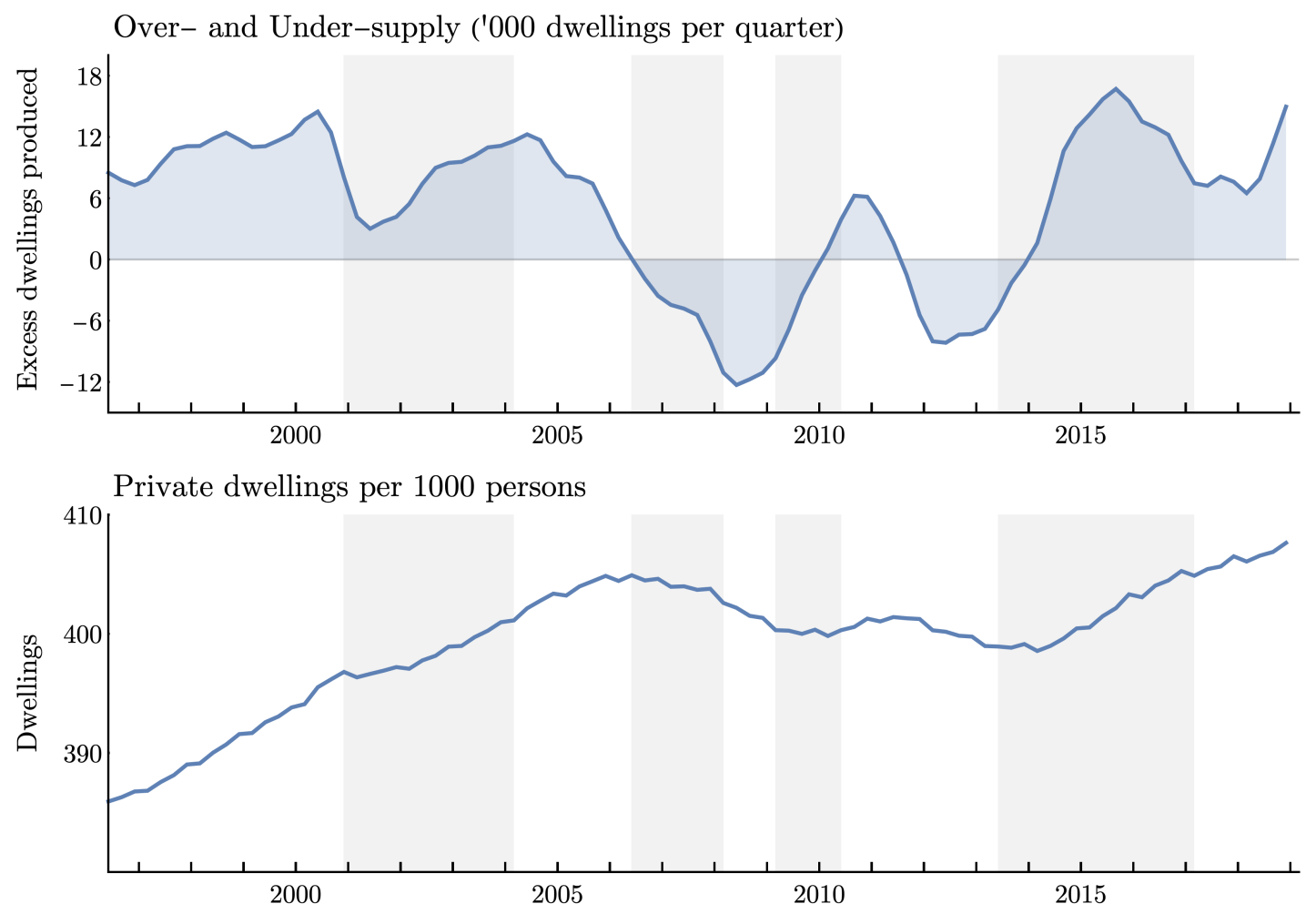

Figure 4: Australian dwelling over-/under-supply and price growth

time gives around 110,000 people accommodated in non-private dwellings that can be subtracted from our final cumulative over-supply figure. Assuming the 2.45 persons per dwelling average, this reduces private housing demand by 45,000 households, leading to an adjusted total oversupply at the end of 2018 of approximately 500,000 dwellings.

The shaded areas of Figure 4 are the periods of sustained price growth of above $2 \%$ per year; the "price booms". To compare the patterns of relative supply and prices we show home price growth in Figure 5. Notice that the national price booms in 2001-04 and 2013-17 were characterised by excess new supply. Only around the financial crisis in 2008-2010, and briefly in 2012-13, was supply less than needed to maintain a constant number of dwellings share per capita. But these periods did not have high price growth. As noted earlier, this decline in supply was due to a combination of lower overall demand for home buying and a shift in buyer preferences towards existing rather than new homes.

We reality-check our above estimates of surplus dwelling construction by looking at the excess of dwellings to households in a different data source (ABS, 2018a). This approach, in Figure 6, shows that the number of dwellings in excess of the number of households; that is, the number of second or empty dwellings (ABS, 2018a). This has grown from its minimum of 180,000 in 2002 ( $2.3 \%$ of the stock of dwellings), to 800,000 (or $8.0 \%$ of the stock) in 2017. If excess dwellings had stayed at the pre-2003 average of $3.3 \%$ of the stock, there would only be only be 320,000 excess dwelling in 2017, implying an over-supply of 480,000 since the early 2000s. The counterfactual growth in excess housing stock if it tracked population growth is also plotted in Figure 6. This 


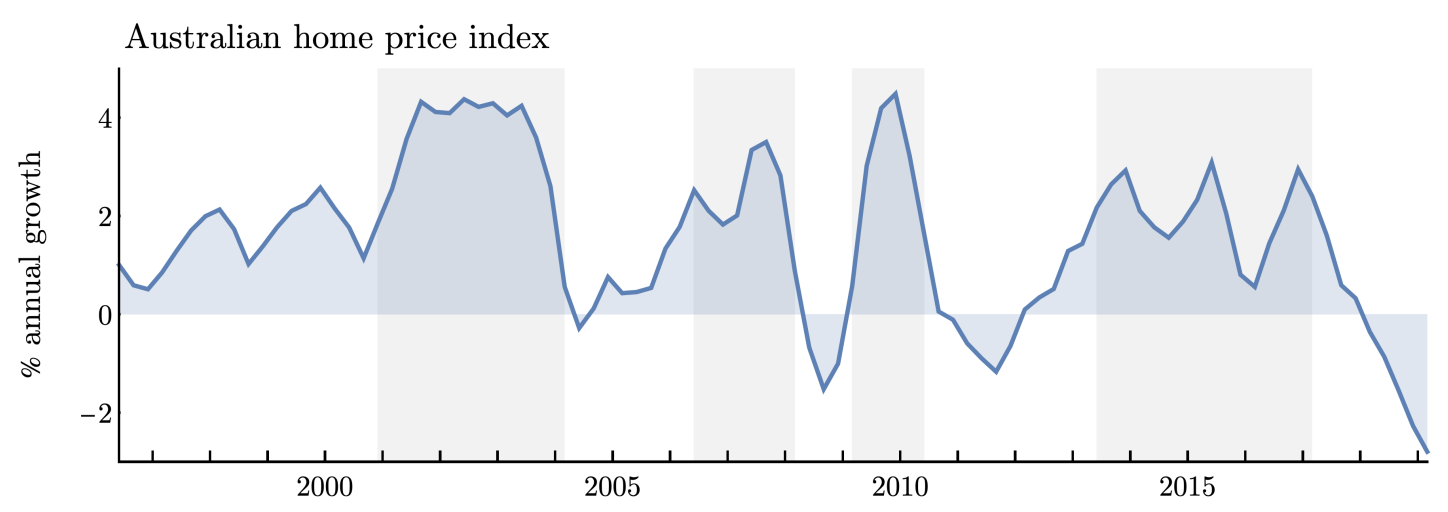

Figure 5: Australian dwelling price growth

data corroborates our previous estimate of 500,000 excess dwellings built in the past two decades.

Dwellings minus households ('000)

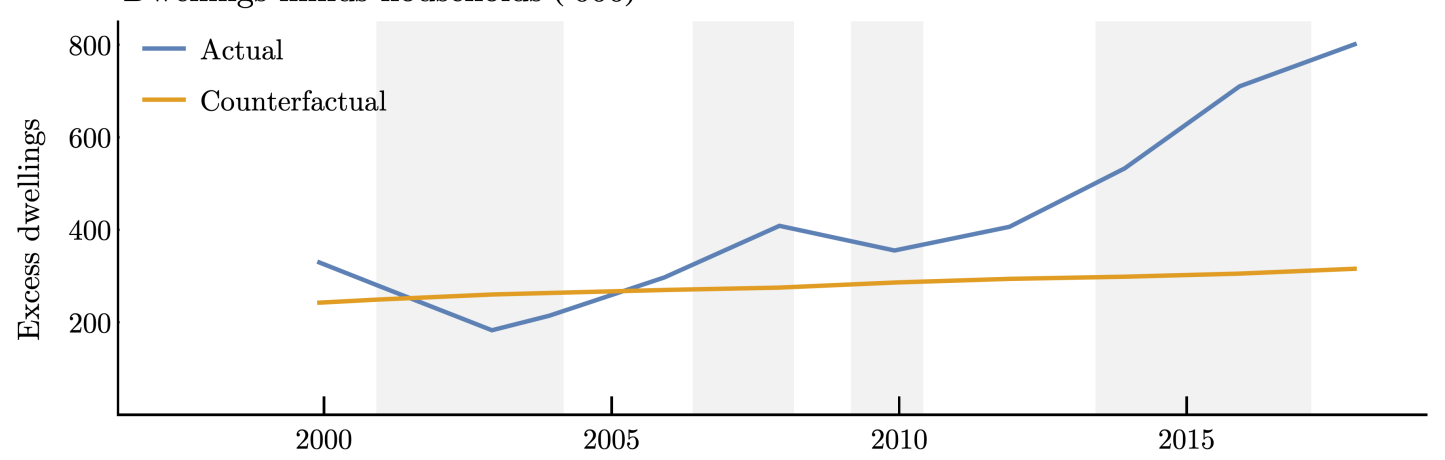

Figure 6: Australian dwelling price growth

\subsection{Reality versus forecasts}

A final way to examine the sufficiency of housing supply is to compare historical forecasts of housing demand and projections of supply with the observed reality. In 2008 the NHSC made its first projections about underlying demand and housing needs for the next decade, outlining the new housing supply necessary to meet their low, medium, and high population demand scenarios (NHSC, 2008). Despite population growth running at record levels since their projection (total population growth was $18 \%$ in the ten years since, but only $14 \%$ in the ten years prior), the observed reality of housing demand was below their lowest projection. Yet, supply was sufficient to meet their medium projection. The NHSC's three demand scenarios for 2008-18 and the actual demand and supply are in Figure 7 showing demand and supply in terms of the number of dwellings. Again we see an excess of supply compared to demand in this period. ${ }^{8}$

\footnotetext{
${ }^{8}$ Actual demand is the increase in households from December 2007 to December 2017, while the actual supply is the increase in private dwellings over the same ten year period (ABS, 2018a).
} 


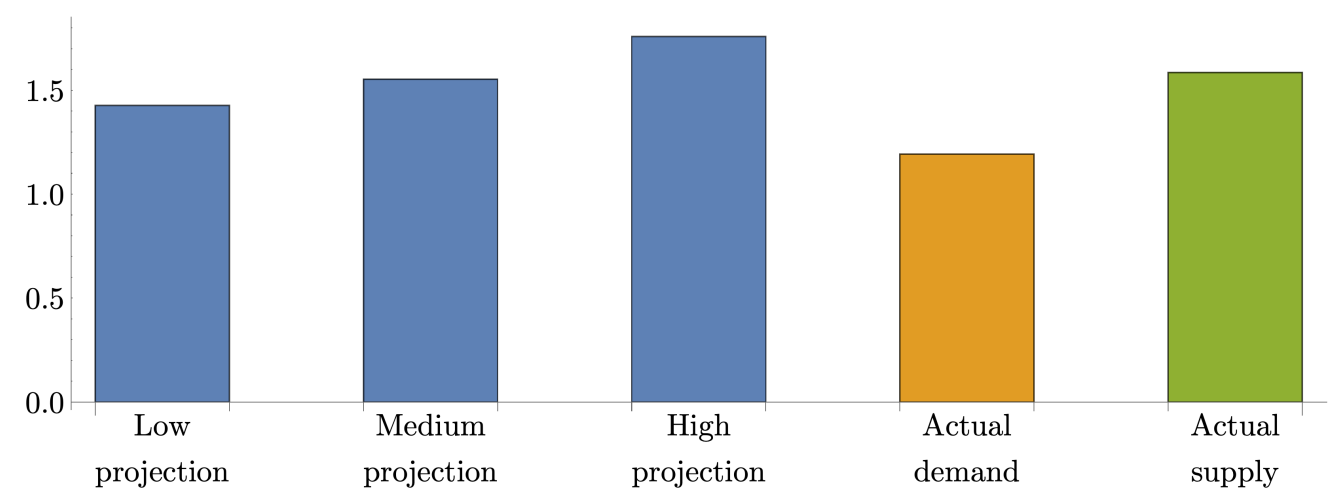

Figure 7: Dwelling demand scenarios and actual demand and supply 2008-2018 (million homes)

\section{How much can planning affect supply?}

An essential element of the housing supply myth is that planning regulations have significant effects on the rate of new housing supply. The calculations in the previous section showed the housing supply has exceeded population growth, but do not address the issue of whether changing the planning system would result in even higher rates of new supply.

Here we show that changing town planning controls to allow dwellings - either more densely, or in more locations - does not automatically lead to these housing development opportunities being taken up faster across the market as a whole. After all, housing developers are not in the business of flooding the market to reduce prices just because they can.

We debunk this part of the myth by showing that planning approvals have greatly exceeded dwelling construction for sustained periods, suggesting that more excess approvals are not going to flow through to supply. We also warn that using the planning system to allow more dense options for development usually provides incentives to delay development. With planning systems having very little ability affect on total housing supply, we argue that the main reason for high home prices is not a lack of supply, but financial conditions in the form of low interest rates and generous access to bank credit (mortgages).

\subsection{Planning changes do not automatically lead to new supply}

We can see that approving more dwellings for construction does automatically result in faster housing construction by looking at the recent history of Sydney. Sydney has been the centre of the supply myth as dwelling prices ballooned $74 \%$ in the five years after 2012 . Yet the data shows that the number of planning approvals for new dwellings greatly exceeded the number of dwellings constructed, as shown in Figure 8 (NSW Government, 2018). Notably, since 1999 the cumulative gap between approvals and completions is 142,000 in Sydney alone, with over 100,000 surplus approvals granted since the 2012 price boom began. The same pattern exists in the Queensland data (Murray, 2019). The ability to secure planning approvals is not a binding constraint on the rate of new dwelling supply.

Additional evidence that new supply is demand-constrained, not planning-constrained, comes from looking at the claims of the industry lobby groups for home-builders and developers. They acknowledge that new housing is only built in response to rising demand-the build-to-order model-and construction falls when demand does. The Housing Industry Association (HIA) have 
Greater Sydney dwelling approvals and completions ('000/year)

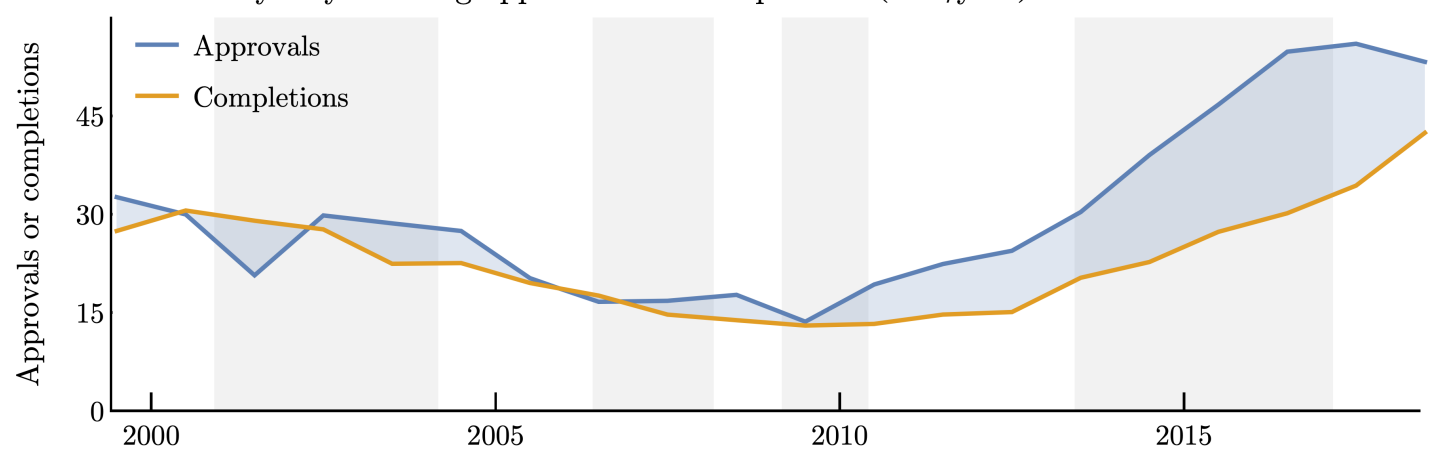

Figure 8: Dwelling approvals and completions in Greater Sydney

explicitly noted this when arguing for demand-side policies to stimulate housing construction, as the following quotations show.

...the HIA is concerned that by limiting demand, the decline in residential construction could be far steeper than what many currently predict.

(Scutt, 2017)

...the HIA says the introduction of tighter lending standards since the end of 2014, seeing lending to investor, interest-only and high debt-to-income borrowers slow, may now be creating additional macroeconomic risks to the Australian economy by making the downturn in residential construction more severe than what would have otherwise been the case

If these disruptions to the home lending environment prove to be long lasting then we could see building activity retreat from the recent highs more rapidly than we currently expect.(Scutt, 2018)

Instead of accepting lower prices in order to sell more new housing, developers reduce their supply. For the supply myth to be true, this cannot happen. Some mechanism is needed to force developers to keep supplying even if prices are falling, just because the planning system allows it.

Similarly, planners can approve at most $100 \%$ of the development applications that are made. They have little control over other decisions, like when to apply for planning permission, or how fast to develop after receiving an approval. In Sydney and Melbourne, 94\% of planning applications are approved, typically in three to four months. Even if there was a direct relationship between the frequency that planning agencies denied applications and the rate of new housing supply, this can at most have a minimal effect (Gurran \& Phibbs, 2014, pp.237-238).

There is also a risk that more relaxed planning controls on housing density could lead to slower rates of new housing supply. It has been known since Titman (1985) that the timing decisions of housing developers are affected by the flexibility of their future development options - the more flexibility to increase the density of a site in the future, the more incentive there is to delay development. You can easily understand this by imagining the effect of announcing a future chance to density controls that would halve the allowable housing density in an area five years in the future. There would be a rush to develop those sites today because the benefits from delaying 
are gone. Timing decision of developers determines the overall rate of housing supply, not the density at which any site can be developed. Yet policies that penalise delay are not yet part of the housing supply debate. Two obvious policy options stand out. First, developer charges (impact fees) can be set at a rate that increments up over time so that there is an incentive to take up those development opportunities in areas zoned for more intensive development sooner rather than later. Second, increasing land value taxes increases the cost of delaying development in general (Mills, 1981).

\subsection{Other culprits - interest rates and demand}

If the supply of housing has been sufficient to meet population demands, indicating that planning is not a cause of high home prices, then what are the main reasons that home prices increased so much in Australia (and globally) over the past two decades?

Differentiating between the causes of home price growth requires separating the price of dwellings as an asset (the home price) from the price of dwellings as a product (the rental price). If home prices are rising but rents are not, then the culprit cannot involve the supply or demand of the product but must involve in some way the financial (and possibly tax) factors that determine the asset price of homes that provide that product.

In Australia, the median rent to income ratio has been flat since 1995 (ABS, 2018a). In 2018 the median private renter spent the same $20.2 \%$ share of income on housing as they did in 1996 . All of the change in home prices over the past two decades, in real economic terms, is, therefore, due to financial factors. A major financial change has been the substantial decline in interest rates which determines how the rental income streams from housing are capitalised into the asset price. Researchers at the Reserve Bank of Australia (RBA) have noted that since 2011 "the reduction in real interest rates accounts for most of the subsequent boom in dwelling prices" (Saunders \& Tulip, 2019, p.25). Lower interest rates are a common feature across global housing markets.

There are also financial factors that determine the demand for owning housing assets, like how easy mortgages are to obtain in terms of deposit requirements and assessments of borrower creditworthiness. These factors also contribute to the divergence between rents and price. Since the Royal Commission, for example, restrictions on mortgage access by banks contributed to price declines while not affecting rents.

At the most basic level, halving the interest rate on mortgages will double prices, all else constant. This is a massive effect compared to any plausible price effects from changing supply, which are assessed in the next section.

\section{How much can supply affect prices?}

\subsection{Scale of price effects}

Housing supply in Australia has been more than sufficient to meet population demand. But is it possible that even higher rates of new housing supply could reduce prices significantly in the future? As we have seen earlier, changing planning regulations are not going to result in faster housing supply and could even backfire. One way to get a large supply boost would be to use a public agency to build housing to meet ambitious supply targets. This agency would need to ignore its profitability or the effect of its supply on market prices, and supply housing at a high rate regardless of demand conditions. It would sell housing to the private market, but could also 
provide non-market social housing. Strangely, a policy of directly building new housing is not the preferred option of proponents of the housing supply myth.

With this reality in mind, we can answer the question of the potential scale of price reductions from higher rates of new housing supply. The first input into this calculation is the relationship between supply and price, holding all else constant, or the price elasticity. Most estimates of the price elasticity of housing are between one and two percent, meaning that for every one percent increase in the total stock of housing, the rent (and hence price) will be one to two percent lower (Mulheirn, 2019). ${ }^{9}$

Since new housing construction changes the total housing stock quite slowly, large changes to the rate of new housing construction are required to generate substantial price-effects. Even some advocates of the supply myth claim that building an additional 50,000 dwellings per year for a decade, a 30\% increase in the rate of new housing supply, will reduce prices by only 5 to $20 \%$ by the end the decade (Daley \& Coates, 2018). To put that number in perspective, in the ten years to 2018 the housing stock increased by 164,000 dwellings per year, or $1.76 \%$ each year on average (up from $1.63 \%$ in the ten years to 2008). Over the same period, prices increased by $61 \%$ (peaking $70 \%$ higher in 2017 before falling in 2018) (ABS, 2018b). ${ }^{10}$

But even this 5-20\% claim is generous. Table 1 shows price reductions under three different supply scenarios and applying two elasticities for each scenario (1\% and $2 \%$ ) to represent the upper and lower bound effects. The supply scenarios include the proposed $30 \%$ per year increase in housing construction rates over ten years, as well as $15 \%$ and $45 \%$ scenarios. Under these simple assumptions, price effects fall in a much lower range of 2 to $15 \%$, and there is a chance that the effect could be even lower if there are countervailing income effects that lead to households outbidding for superior locations. In the most extreme scenario, if Australia had radically increased new housing supply by $45 \%$ for the past decade, prices would have increased only $36 \%$ instead of the $60 \%$ they increased in reality.

Table 1: The price effect of a ten-year increase in housing supply

\begin{tabular}{cc|cc}
\hline \hline $\begin{array}{c}\text { Construction } \\
\text { rate increase }\end{array}$ & $\begin{array}{c}\text { Total additional } \\
\text { dwellings }\end{array}$ & \multicolumn{2}{|c}{ Total price reduction } \\
1\% elasticity & $2 \%$ elasticity \\
\hline $15 \%$ & 247,000 & $2.4 \%$ & $4.8 \%$ \\
$30 \%$ & 494,000 & $4.8 \%$ & $9.6 \%$ \\
$45 \%$ & 740,000 & $7.2 \%$ & $14.4 \%$ \\
\hline \hline
\end{tabular}

\subsection{The cost of faster housing supply}

One critical economic point that is rarely considered in calls to build more housing that there is a real economic cost to doing so. Significant increases in the rate of new housing construction have macroeconomic costs in the form of alternative production opportunities forgone to dedicate additional labour and capital inputs to housing.

Housing construction already directly accounts for about $25 \%$ of total investment in the economy, $5 \%$ of gross domestic product (GDP), and about $6 \%$ of the workforce (ABS, 2019b,a; Debelle,

\footnotetext{
${ }^{9}$ A price-elasticity of one would imply that total housing rents are maximised.

${ }^{10}$ Prices in the previous ten year period to December 2008 increased $93 \%$.
} 
2019). ${ }^{11}$ This implies that to achieve the $45 \%$ higher construction scenario in Table $1,3 \%$ of the labour force (one in thirty workers) would need to shift out of what they are doing and in to housing construction. ${ }^{12}$ These labour requirements are consistent with the historical record, where the share of the workforce in dwelling construction increased from $4 \%$ to $6 \%$ as construction grew to historic highs in the mid-2000s. Any account of the potential benefits from additional housing supply on the price of housing must take into account these costs.

\section{Conclusions}

The evidence against Australia's housing supply myth is clear. Not only do its claims conflict with the financial interests of its proponents, the data shows that housing supply has exceeded population needs. If anything, housing supply has had a negative effect on price growth over the past two decades. Dwellings approved by the planning system have exceeded dwelling constructed by over 100,000 in the past nine years in Sydney alone. With $94 \%$ of all planning applications approved, there seems little scope for the planning system to force more new supply onto the market. Indeed, there is no clear mechanism available for planners to force either more applications to be made or for approved housing to be sold and built more rapidly. Even if housing supply was radically increased, the price effects would be minimal, and the macroeconomic costs substantial. Other factors like low interest rates and generous mortgage lending appear to be the main drivers of home price growth in Australia in the past two decades.

This evidence can help combat the housing supply myth and any misdirected political interference in the planning system that accompanies it. With the expected construction cycle downswing likely to be amplified by a shift in buyer preferences away from new apartments, there will be a strong incentive to blame planning for the downswing, especially when prices begin to rise again. A story about home prices being mostly driven by financial factors, and housing supply decisions being driven mostly by the economic incentive of landowners to delay, could be a powerful counter-narrative.

\section{References}

ABS. 2016. 2016 Census Quickstats. Greater Sydney. Tech. rept. Australian Bureau of Statistics.

ABS. 2018a. 4130.0 - Housing Occupancy and Costs, 2017-18. Tech. rept. Australian Bureau of Statistics.

ABS. 2018b. 6416.0 Residential Property Price Indexes: Eight Capital Cities.

ABS. 2019a. 5206.0 - Australian National Accounts: National Income, Expenditure and Product, Jun 2019. Tech. rept. Australian Bureau of Statistics.

ABS. 2019b. 6202.0 - Labour Force, Australia, Aug 2019. Tech. rept. Australian Bureau of Statistics.

ACT Legislative Assembly. 2018. Inquiry into building quality in the ACT. Tech. rept.

\footnotetext{
${ }^{11}$ Counting building construction and apportioning half of the building services employment to housing and its related construction needs.

${ }^{12}$ One could argue that there is a macroeconomic stimulus effect from higher construction that would reduce unemployment. However, again, there is a cost of forgone alternative non-housing stimulatory investments that could have instead been made.
} 
CAsben, Liv. 2019. Mascot Towers' residents vote to pay $\$ 7$ million in levies as repair bill blows out to $\$ 20$ million.

COAG. 2012. Housing Supply and Affordability Reform. Council of Australian Governments.

Corelogic. 2016. Profile of the Australian residential property investor.

CREA. 2019. MLS Home Price Index (HPI). Tech. rept. The Canadian Real Estate Association.

Daley, John, \& CoAtes, Brendan. 2018. Housing affordability: re-imagining the Australian dream. Tech. rept. Grattan Institute.

Daley, John, Goss, Peter, Duckett, Stephen, Norton, Andrew, Terrill, Marion, Wood, Danielle, Wood, Tony, \& Coates, Brendan. 2019. Commonwealth Orange Book 2019: Policy priorities for the federal government. Tech. rept. Grattan Institute.

DCLG. 2017 (February). Fixing our Broken Housing Market. Tech. rept. Department of Communities and Lcoal Government.

Debelle, Guy. 2019 (October). Housing and the Economy. Tech. rept. Reserve Bank of Australia.

Department of the Senate. 2008. A good house is hard to find: Housing affordability in Australia. Tech. rept. Select Committee on Housing Affordability in Australia.

FIRB. 2018. Annual report 2017-18. Chapter 3. Tech. rept. Foreign Investment Review Board.

Glaeser, Edward, \& Gyourko, Joseph. 2018. The Economic Implications of Housing Supply. Journal of Economic Perspectives, 32(1), 3-30.

Gurran, Nicole, \& Phibbs, Peter. 2013. Housing supply and urban planning reform: the recent Australian experience, 2003-2012. International Journal of Housing Policy, 13(4), 381-407.

Gurran, Nicole, \& Phibbs, Peter. 2014. Evidence-free zone? Examining claims about planning performance and reform in New South Wales. Australian Planner, 51(3), 232-242.

HANMER, GEOFF. 2019. Lacrosse fire ruling sends shudders through building industry consultants and governments.

Johnston, Nicole, \& Reid, Sacha. 2019. An examination of building defects in residential multi-owned properties.

Kearns, Jonathan. 2017. Australian Property - Financial Stability and Foreign Involvement. Tech. rept. Reserve Bank of Australia.

Kendall, Ross, \& Tulip, Peter. 2018. The Effect of Zoning on Housing Prices. Research Discussion Paper 2018-03. Reserve Bank of Australia.

Knight Frank. 2018. Student Housing 2018 - Sector Review - Market Outlook. Tech. rept. Knight Frank Research and Consulting.

Lendlease. 2019. Annual Report 2018-19. Tech. rept.

Loseby, Kathlyn. 2019. Greed and speed before quality: the equation behind Sydney's building crisis.

McConnell, Allan. 2018. Rethinking wicked problems as political problems and policy problems. Policy \& Politics, 46(1), 165-180. 
Mills, David E. 1981. The non-neutrality of land value taxation. National Tax Journal, 34(1), 125-129.

Mulheirn, IAn. 2019. Tackling the UK housing crisis: is supply the answer? UK Collaborative Centre for Housing Evidence.

Murray, Cameron. 2019. Time is money: How landbanking constrains housing supply. Available at SSRN 3417494.

Murray, Cameron, \& Frijters, Paul. 2017. Game of Mates: How favours bleed the nation. Cameron Murray.

NHSC. 2008. State of Supply Report. Tech. rept. National Housing Supply Council.

NHSC. 2013. 2013 State of Supply Report: Changes in how we live. Tech. rept. National Housing Supply Council.

NSW Government. 2018. Metropolitan Housing Monitor. Tech. rept. NSW Department of Planning and Environment.

NSW PARLIAMENT. 2019. Regulation of building standards, building quality and building disputes. Tech. rept.

ONS. 2019. UK House Price Index. Tech. rept. HM Land Registry. Office for National Statistics.

Phillips, Ben, \& Joseph, CukKoo. 2017. Regional housing supply and demand in Australia. Centre for Social Research 8 Methods. Canberra: Australian National University.

Philp, Chris. 2017. Homes for Everyone: How to get Britain building and restore the home ownership dream. Tech. rept. Centre for Policy Studies.

Productivity Commission. 2017. Shifting the Dial: 5 year productivity review. Chapter 4: Better functioning towns and cities. Tech. rept. Australian Government.

RBA. 2019. Lending Rates - F5. Tech. rept. Reserve Bank of Australia.

SAiz, AlBert. 2010. The geographic determinants of housing supply. The Quarterly Journal of Economics, 125(3), 1253-1296.

Saunders, Trent, \& Tulip, Peter. 2019. A Model of the Australian Housing Market. Reserve Bank of Australia Discussion Paper Series, 1.

ScutT, DAVID. 2017. Why trying to 'fix' Australia's housing market could just create even more problems. Business Insider, Australia, 24 August.

ScutT, DAVID. 2018. The HIA warns Australia's housing construction downturn could get nasty unless credit continues to flow. Business Insider, Australia, 19 November.

S\&P. 2019. S\&P/Case-Shiller U.S. National Home Price Index.

Stockland. 2019. Annual Report 2018-19. Tech. rept.

Titman, Sheridan. 1985. Urban land prices under uncertainty. The American Economic Review, 75(3), 505-514.

UDIA. 2019 (January). National Pre-Budget Submission 2019. "Building a Better Australia". Urban Development Institute of Australia. Australian Treasury Submission. 
USCB. 2018a. Selected housing characteristics. Housing Units. Atlanta-Sandy Springs-Roswell. Tech. rept. U.S. Census Bureau.

USCB. 2018b. Selected housing characteristics. Housing Units. Houston-Sugar Land-The Woodlands. Tech. rept. U.S. Census Bureau.

USCB. 2019a. New Private Housing Structures Authorized by Building Permits for AtlantaSandy Springs-Alpharetta, GA (MSA) [ATLA013BPPRIVSA], retrieved from FRED, Federal Reserve Bank of St. Louis. Tech. rept. U.S. Census Bureau.

USCB. 2019b. New Private Housing Structures Authorized by Building Permits for Houston-The Woodlands-Sugar Land, TX. Tech. rept. U.S. Census Bureau.

Victorian Cladding Taskforce. 2019. Report from the co-chairs. Tech. rept. The State of Victoria Department of Environment, Land, Water and Planning.

Wilson, Wendy, \& Barton, Cassie. 2018. Tackling the under-supply of housing in England. Briefing Paper 07671. House of Commons Library.

YGlesias, Matthew. 2012. The rent is too damn high: What to do about it, and why it matters more than you think. Simon and Schuster. 